\title{
Effects of fiscal decentralization on economic growth and human development index in the Indo- nesian local governments
}

\author{
Nahu Daud ${ }^{a^{*}}$ and Rusman Soleman ${ }^{a}$
}

${ }^{a}$ Universitas Khairun, Ternate, Indonesia

\section{H R O N I C L E}

Article history:

Received: May 30, 2020

Received in revised format:

May 302020

Accepted: July 9, 2020

Available online:

July 9, 2020

Keywords:

Fiscal decentralization

Economic growth

Human development index

\section{A B S T R A C T}

The implementation of regional autonomy has implications for the transfer of authority between the center and the regions in various fields. The existence of regional autonomy will result in decentralization which involves the management of regional finances, economic planning, including arranging regional development programs and other plans delegated from the center to the regions. The purpose of this study was to examine the effect of fiscal decentralization on economic growth and the index of human development in districts and cities in North Maluku Province. The population of this study consisted of 7 districts and 2 cities. The data is secondary data for the period 2011 to 2015, sourced from the Central Statistics Agency (BPS) Jakarta, districts and cities in North Maluku Province, published. The collected data were analyzed using path analysis techniques using the SPSS program package. The results of the study indicate that the effect of fiscal decentralization on economic growth had a positive path coefficient with a level of probability which was not significant. This shows that hypothesis one which states that fiscal decentralization has a significant effect on the economic growth of districts and cities in North Maluku Province. These results suggest that the higher the fiscal decentralization, the higher the economic growth. The effect of fiscal decentralization on the human development index has a positive path coefficient with a significant level of probability. This implies that the higher the fiscal decentralization, the higher the human development index. The effect of economic growth on the human development index has a positive coefficient with a significant level of probability. These results indicate that the higher the economic growth, the higher the index of human development.

C) 2020 by the authors; licensee Growing Science, Canada

\section{Introduction}

The implementation of regional autonomy is basically a response to the aspirations of a new format regarding the relationship between the central government and the regional government in Indonesia, which has implications for the delegation of authority in various fields. In line with the division of authority, the regional financing arrangements are based on the principles of governance. The implication of granting autonomy authority requires the region to be able to provide public goods that are local. Therefore, with decentralization, it is hoped that the Regional Government can provide better public services and create a more democratic public decision-making process. Financing of government administration based on the principle of decentralization is charged through the regional government budget, financing of government administration in the framework of implementing the principle of deconcentration which is carried out at the expense of the state budget and financing of government administration in the framework of co-administration is funded by the assigning government-level budget burden. This decentralization also includes fiscal decentralization. Fiscal decentralization is a major component of decentralization, where local governments in carrying out their functions are given the freedom to make spending decisions in the public sector. However, the decision must be supported by the central government such as subsidies/assistance and 
loans from the central government as well as adequate financial resources, both originating from local own-source revenues (PAD), tax and non-tax revenue sharing. Development of regional budget which includes; PAD, balance funds and other income that are legalized by regencies/cities in North Maluku province can be seen in Tables 1. Table 1 illustrates the revenue of regencies/cities in North Maluku Province during the period of 2011 to 2015. In Table 1 as a whole it appears that the development of district/city regional budget in North Maluku Province during that period has shown an increasing development.

Table 1

Regional budgets, original revenues and balance funds in North Maluku Province (2013-2015, in billions of rupiah)

\begin{tabular}{|c|c|c|c|c|c|c|c|c|c|}
\hline \multirow[t]{2}{*}{ District/year } & \multicolumn{3}{|c|}{2013} & \multicolumn{3}{|c|}{2014} & \multicolumn{3}{|c|}{2015} \\
\hline & budget & revenues & fiscal & budget & revenues & fiscal & budget & revenues & fiscal \\
\hline Central Halmahera & 510,473 & 28,877 & 467,308 & 551,712 & 17,275 & 508,451 & 546,974 & 13,210 & 510,955 \\
\hline Ternate & 646,699 & 40,572 & 548,427 & 772,962 & 57,765 & 634,404 & 812,541 & 60,808 & 639,964 \\
\hline West Halmahera & 505,214 & 10,215 & 468,271 & 563,573 & 15,407 & 519,651 & 649,446 & 31,740 & 556,656 \\
\hline East Halmahera & 609,295 & 94,994 & 495,540 & 600,425 & 28,579 & 532,858 & 611,015 & 43,553 & 522,309 \\
\hline South Halmahera & 668,151 & 31,101 & 611,891 & 729,212 & 28,651 & 648,555 & 790,327 & 39,106 & 685,906 \\
\hline North Halmahera & 612,139 & 103,330 & 481,202 & 728,325 & 115,814 & 553,228 & 762,940 & 124,431 & 578,445 \\
\hline Sula Islands & 558,083 & 19,029 & 515,823 & 499,256 & 12,126 & 442,954 & 618,204 & 27,065 & 544,008 \\
\hline Tidore Islands & 580,940 & 16,351 & 531,496 & 651,764 & 27,672 & 578,229 & 689,575 & 33,201 & 601,704 \\
\hline Morotai Island & 437,772 & 7,979 & 417,879 & 446,651 & 5,425 & 426,782 & 777,062 & 55,585 & 674,184 \\
\hline
\end{tabular}

The receipt of district/municipal balance funds during the period of 2011 to 2015 has shown an increase. In general, it appears that the contribution of balancing funds to regional revenues is quite high, when compared to the contribution of regional own-source revenues (PAD) to regional budget. The average contribution of Regency/City PAD in North Maluku Province is still below $10 \%$. The low proportion of PAD revenue compared to the balance fund indicates that local governments are not yet optimal in exploring sources of revenue. It can be said that in general regional government revenue is still dominated by transfers from the central government in the form of general allocation fund (DAU) and Tax and Non-Tax balance fund (BHPBP).

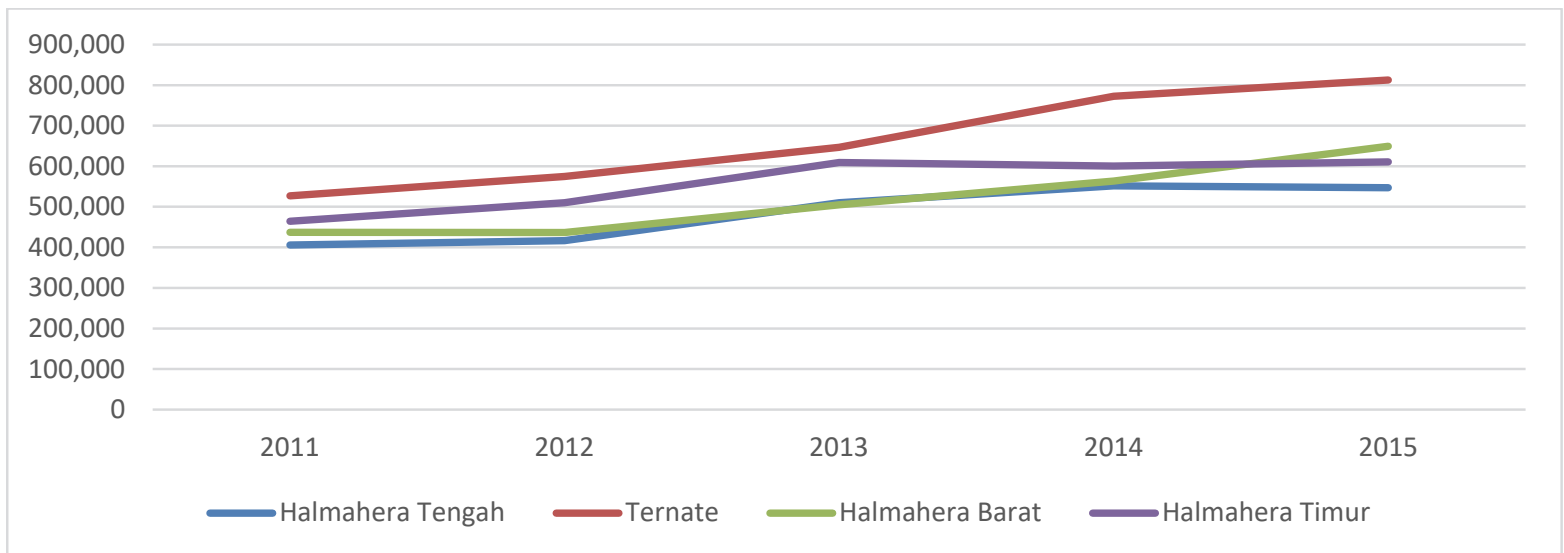

Fig. 1. Trend of Budget Increases in Selected Regions

Fiscal decentralization indirectly has a relationship to economic growth because it can increase efficiency in resource allocation (Bird \& Vaillancourt, 2000). The essence of the relationship between economic growth and fiscal decentralization has at least three considerations.

1. Growth is seen as being objective in terms of fiscal decentralization and efficiency in the allocation of resources in the public sector.

2. Explicitly that the government is trying to adopt various policies to drive towards an increase in per capita income.

3. Growth per capita is relatively easier to measure and interpret than other economic indicators.

In addition, fiscal decentralization is also expected to improve people's welfare (Bappenas, 2007). The main objective of the policy of regional autonomy and fiscal decentralization is to accelerate the realization of improving the people welfare. The question to be answered in this study is whether fiscal decentralization has a positive and significant impact on the economic growth of districts/cities in North Maluku Province. Second, whether fiscal decentralization has a positive and significant effect on the district/city human development index in North Maluku Province. Third, whether economic growth has a positive and significant effect on the district/city human development index in North Maluku Province. 


\section{Literature Review}

\subsection{Fiscal Decentralization}

The government basically has three main functions, including the function of distribution, allocation and stabilization (Musgrave, 1985). The allocation function is the role of the government in allocating economic resources to be created efficiently, namely the role of the government in the supply of goods or services that cannot be provided through transactions between sellers and buyers or the market system due to market failures. Therefore, the government must provide these goods (in this case public goods). The distribution function and the stability function are generally more effective and appropriately carried out by the central government, while the allocation function by the regional government is more aware of the needs, conditions and situation of the local community. The division of these three functions is intended as a basis for determining the basics of financial balance between the central and regional governments. Financial balance between the central and regional governments includes but is not limited to the distribution of finance between the central government and the regions proportionally, transparently, democratically and fairly by taking into account regional conditions, potentials and needs. Decentralization in general illustrates the transfer of competence and ability and responsibility to carry out better public service obligations from the central to the regional governments. In addition, decentralization can be interpreted as the transfer of functions and resources from the central government to regional governments. In terms of functions, where the provision of functions or services provided by the central government must provide benefits in a broader economic sphere. Fiscal decentralization is a major component of decentralization, where if the regional government carries out its functions and is given freedom in making expenditure decisions in the public sector then it must receive support from the Central Government in the form of subsidies/assistance or loans from the Central Government as well as adequate financial sources, both of which comes from regional own-source revenue (PAD), tax and non-tax profit sharing. The function of distribution is the role of government in influencing the distribution of income and wealth to ensure fairness or "fair" in regulating income distribution. The stabilization function refers to government actions in influencing the overall level of unemployment, economic growth and prices. In this case, the government uses a budget policy (budget policy) to reduce unemployment, the degree of reasonable price stability and the level of sustainable economic growth. Fiscal decentralization indirectly has a relationship to economic growth because it can increase efficiency in resource allocation (Bird \& Vaillancourt, 2000).

\subsection{Economic growth}

One method commonly used in assessing the effect of development on people's welfare is to study the distribution of income. The distribution of income by income classes (the size distribution of income) can be measured using the Lorenz curve or the Gini index. In addition to the distribution of income, the impact and results of development can also be measured by looking at the level of poverty in a country. Unlike the income distribution that uses the relative concept, analysis of poverty levels uses the concept of absolute or absolute poverty. Although development must be equitable, it is recognized that growth remains important. Efforts to integrate the concepts of growth and equity are challenges whose answers are continually sought in development studies. A model, called redistribution with growth (RWG), was developed based on a study sponsored by the World Bank in 1974 (Chenery et al., 1974). The basic idea is that the government should influence the pattern of development in such a way that low-income people (who in many countries are located in rural areas and small producers in urban areas) will have the opportunity to increase income and simultaneously receive the necessary economic resources. Still in the context of seeking answers to the challenges of the justice paradigm in development, a basic human needs (BHN) approach has developed (Streeten et al., 1981). The BHN strategy is structured to provide basic goods and services for the poor, such as staple food, water and sanitation, health care, basic education and housing. Although RWG and BHN have the same goal, the two are different in terms of the policies taken. RWG emphasizes on increasing productivity and purchasing power of the poor, while BHN emphasizes on providing public services accompanied by guarantees to the poor in order to obtain these services. The problem of unemployment is also getting more attention in the context of economic development that requires equality. Todaro (1977) suggests that there is a close relationship between unemployment, income inequality, and poverty. In general, those who cannot get jobs regularly are those who belong to the poor community group. Those who get jobs continuously are middle and high income people. Thus, solving the problem of unemployment can solve the problem of poverty and income distribution. Equitable distribution of income will increase job creation (Seers, 1970). According to this theory goods consumed by the poor tend to be more labor-intensive compared to the consumption of higher-income people. Thus, income equality will cause a shift in demand patterns which in turn will create job opportunities.

\subsection{Human Development Index}

According to the United Nations Development Program (UNDP), in the Human Development Index (HDI) there are three composite indicators used to measure the average achievement of a country in human development, namely: length of life, as measured by life expectancy at birth; education measured based on average length of schooling and literacy rates of people aged 15 years and over; standard of living measured by per capita expenditure that has been adjusted to purchasing power parity. This index value ranges from 0-100. The concept of complete human development is a concept that requires an increase in the quality of life of the population both physically, mentally and spiritually. Even explicitly stated that the development carried out focuses on the development of human resources in line with economic growth. Development of human resources 
physically and mentally implies an increase in the basic capacity of the population which will then enlarge the opportunity to be able to participate in a sustainable development process. Human Development Index, because it is intended to measure the impact of efforts to improve these basic abilities, thus using the impact indicator as a basic component of its calculation, namely life expectancy at birth, educational attainment measured by literacy rates and average length of schooling, and expenditure consumption.

\section{Research Methods}

\subsection{Research design}

This research is a study that explains the causal relationship between variables or so-called explanatory research that is research to find out and explain the influence between existing variables and proceed with hypothesis testing. In addition, this study is included in the developmental research, because it provides an explanation of the developments regarding the variables to be examined. In this study the effects of fiscal decentralization on economic growth and the index of human development in districts and cities in the Maluku Utara Province will be analysed. This study uses secondary data (time series) and cross section data or pooled data. The time series data will illustrate the data on the development of fiscal decentralization, economic growth and the human development index, while the Croos section data shows the number of districts and cities in Maluku Utara Province which are used as research objects.

\subsection{Variable Classification}

In this study there are several variables that can be identified, namely:

1. Fiscal Decentralization as an exogenous or independent variable (X)

2. Economic growth as the first endegon variable or dependent variable (Y1)

3. Human development index as the second endogenous variable or dependent variable (Y2).

\subsubsection{Analysis Techniques}

The analysis technique used in this study is path analysis. This analysis was developed as a method for studying the effects, either directly or indirectly, of the independent variables on the dependent variable. This analysis is an option in order to study the dependence of a number of variables in the model. Path analysis is also used to examine the relationships between causal models that researchers have formulated on the basis of certain theoretical considerations and knowledge. Causal relationships are based not only on data, but also based on knowledge, formulation of hypotheses and logical analysis, so that it can be said path analysis can be used to test a set of causal hypotheses and to interpret these relationships. The path diagram model can also be expressed with equations, thus forming a system of equations. The system of equations is called a system of simultaneous equations, or also often called structural models.

1. $\mathrm{Y}_{1}=\mathrm{P}_{1} \mathrm{X}+\varepsilon_{1}$

2. $\mathrm{Y}_{2}=\mathrm{P}_{2} \mathrm{X}+\mathrm{P}_{3} \mathrm{Y}_{1}+\varepsilon_{2}$

$\mathrm{X}=$ degree of fiscal decentralization; $\mathrm{Y} 1=$ economic growth; $\mathrm{Y} 2=$ Community welfare; $\mathrm{P} 1$ to $\mathrm{P} 3$ = path coefficient.

\section{Results}

\subsection{Effects of Fiscal Decentralization on Economic Growth}

The results of studies showed that fiscal decentralization has a positive effect, names do not have a significant effect on economic growth. This is indicated by the path coefficient that is positive with a value of 0.013 with a C.R value of 0.083 and a probability probability (p) of 0.938 greater than the significance level $(\alpha)$ determined at 0.05 . This shows that hypothesis one which states "fiscal decentralization has a positive and significant effect on economic growth in districts and cities in Maluku Province is unacceptable", because it is not empirically proven. The results of this study are in line with the study of Davoodi and Zou (1997) who examined fiscal decentralization with economic growth: cross country study and found for developing countries there is a negative relationship and also for the world, while for developed countries there is no relationship for countries advanced. The results of this study are also supported by studies conducted by Braun and Grote (2000) on decentralization and poverty finding public financing is a major element of poverty reduction policies. However, countries with low incomes have problems with low public revenues, which on average reach 17.5\%. Meanwhile for highincome countries revenue is almost $30 \%$. In the regions there are problems with the design and implementation of tax collection that are not well organized, less transparent. The cost of collecting income in poor countries is very high and sometimes exceeds the profits from public spending. However, the real problem is the limited public resources such as education, health, which can help the poor to accumulate their assets. In relation to the results of previous studies both in terms of similarities and differences with this study, it can be concluded that, there is a relatively small positive effect of fiscal 
decentralization on economic growth that is, related to the problem of extracting sources of regional revenue, including tax and Regional retribution which is one of the sources of revenue from the region's original revenue has not been able to make a significant contribution to overall regional revenue so that in the end it is unable to encourage regional economic growth. The insignificant role of regional income in the regional government budget cannot be separated from the tax system in Indonesia which still gives full authority to the Central Government to collect potential taxes, such as: income tax, value added tax and import duties. The fact that occurs so far the distribution of tax authority between the regions and the center is very lame, namely the amount of tax revenue collected by the region is only 3.39\% of the total tax revenue (Sidik, 2002). Inequality in the authority of the sources of tax revenue provides a clue that the financial balance between the Central and Regional Governments in Indonesia, especially in terms of revenue is highly controlled or dominated by the Central Government. This has an impact on the still low role of the Regional Government budget in driving economic growth through the revenue side.

\subsection{Effects of Fiscal Decentralization on the Human Development Index}

The test results show that the effect of fiscal decentralization on the human development index has a path coefficient of 0.364 with a C.R value of 2.605 and a probability level of 0.013 smaller than $(\alpha)=0.05$. This shows that the second hypothesis stating that fiscal decentralization has a positive and significant effect on the district and city human development index in North Maluku Province is proven to be true and acceptable. The results of this study are in line with the study of Brata (2005) which states that government spending in education and health has a positive and significant influence on the level of human development. This can show that the greater the allocation of development spending on education and health the better the Human Development Index (HDI) achieved.

Table 2

Hypothesis Testing

\begin{tabular}{llllll}
\hline Hypotheses & & & Estimate & C.R & p-value \\
\hline Fiscal decentralization & $\mathbf{7}$ & Economic growth & 0.013 & 0.083 & 0.938 \\
Fiscal decentralization & $\mathbf{7}$ & Human Development Index & 0.364 & 2.605 & 0.013 \\
Fiscal Decentralization & $\mathbf{7}$ & Human Development Index & 0.239 & 2.048 & 0.048 \\
\hline
\end{tabular}

The results of this study are supported by studies conducted by Word Bank (2003) regarding the ideal district and city growth models, which emphasize efforts to improve public services. That good governance will encourage the provision of high quality district and city services, so that investors will be interested in the progress so as to stimulate regional economic development and improve the quality of life for all people including the poor. Then the results of this study also support the results of Rappaport's (1999) study of economic growth between regions in the United States states that in terms of the relationship between local government budget policies with local economic growth shows that local economic growth during the period observed was positively correlated with local government expenditure on primary and secondary education. Cherniavskii and Vartapetov (2005) stated that the contribution of PAD in total regional revenue can be seen as an indicator of regional financial autonomy. It was further explained that the receipt of PAD increased the opportunity to allocate PAD for various purposes.

\subsection{Effect of Economic Growth on the Human Development Index}

The results of the third hypothesis test show that the effect of economic growth on people's welfare has a path coefficient of 0.239 with a C.R value of 2.048 and a significance probability (p) of 0.048 which is smaller than the significance level $(\alpha)$ determined at 0.05 . This shows that hypothesis three which states that economic growth has a positive and significant influence on the human development index of districts and cities in Maluku Province is acceptable. This shows that if economic activity in the region is increased and economic growth increases, the human development index will also increase. The results of this study support the results of Brata's (2002) study of local public sector investment, human development and poverty. The results of the study said that economic development has a significant effect on people's welfare, as indicated by human development, which means that economic development has been able to improve the socio-economic development of the community. The results of this study are not in line with the study of Tadjoeddin et al (2001) regarding regional disparities and vertical conflicts in Indonesia. The study concludes that the relationship between the level of output in an area with the level of community welfare in the area concerned is very weak. The high wealth of the region is not significantly followed by a high level of community welfare. Meanwhile, according to Suharto's (2005) opinion that the diversity of human resources and the economic potential of the region often generates the view of generalization that development of community welfare only needs to be done by regions that have high economic capacity. Decentralization, which gives broader authority to the regions, is then used as a momentum to cut budgets and community institutions and even eliminate the same.

\section{Conclusion}

Analysis of the effects of fiscal decentralization on economic growth and the human development index in North Maluku Province, the results of the study found that fiscal decentralization has a positive but not significant effect on economic growth. This result does not provide support for hypothesis one which states that fiscal decentralization has a significant effect on 
economic growth. Second, the results revealed that fiscal decentralization positively and significantly affected the human development index. These results provide support for hypothesis two which states that fiscal decentralization has a significant effect on the human development index. Positive direction indicates that increasing fiscal decentralization will increase the index of human development. Testing the effect of economic growth on the human development index found that economic growth had a positive and significant effect on the human development index. These results provide support for hypothesis three which states that economic growth has a significant effect on the human development index. Positive direction indicates that increasing economic growth will lead to an increase in the human development index. This finding practically implies that the fiscal decentralization of regencies/cities in North Maluku province is still low, a sign that the level of regional financial dependence on the central government is still very high. Thus very precise policies are needed from all aspects to fix this. Practically, this study underlines that local governments should optimize their sources of regional income. Regional innovation and creativity is needed in this regard, so that the components of local revenue that are the concentration of local government should not only come from taxes and fees. The problem that occurs due to the weakness of local own-source revenue is that the regions do not encourage the performance of regional owned enterprises they have. Next, the central government must reformulate the policy on revenue sharing. If the revenue-sharing funds are still held by the central and regional governments only given a "small" proportion, then it is possible that at any time the region will not have a high degree of fiscal decentralization. In the context of a hierarchical relationship with the central government, the central government must of course also emphasize the oversight function in terms of tax collection and regional levies, so that local taxes and levies can return to their functions aimed at equity and justice, not only burdening the people. The balancing fund policy consisting of general allocation fund (DAU), special allocation fund (DAK), and revenue sharing funds (DBH) needs to be reviewed in proportion. Because the proportion of General Allocation Funds whose components consist of employee expenditure. Indirectly, this personnel expenditure makes the burden of the central government increases, therefore the government must review the proportion of each balance fund given to the regions.

\section{References}

Bird, R. M., \& Vaillancourt, F. (2000). Fiscal decentralization in developing countries. Jakarta: PT Gramedia Pustaka Utama. Brata, A. G. (2005). Local public sector investment, Human Development and Poverty. Atmajaya University Research Institute.

Braun, J. V., \& Grote, U. (2000). Does Fiscal Decentralization Serve the Poor. In IMF Conference on Fiscal Decentralization, Center for Development Research (ZEF-Bonn), Washington, DC.

Chenery, H., Ahluwalia, M. S., Duloy, J. H., Bell, C. L. G., \& Jolly, R. (1974). Redistribution with growth; policies to improve income distribution in developing countries in the context of economic growth. Oxford University Press.

Cherniavskii, A., \& Vartapetov, K. (2005). Fiscal decentralization and local government in the reform period. Problems of Economic Transition, 47(11), 18-36.

Davoodi, H., \& Zou, H. F. (1998). Fiscal decentralization and economic growth: A cross-country study. Journal of Urban Economics, 43(2), 244-257.

Ministry of National Development Planning / National Development Planning Agency (Bappenas). (2007). Report on the progress of Indonesia's 2007 millennium development goals. Jakarta: Ministry of National Development Planning / National Development Planning Agency (Bappenas).

Musgrave, R. A. (1985). A brief history of fiscal doctrine. In Handbook of public economics (Vol. 1, pp. 1-59). Elsevier.

Rappaport, J. (1999). Local growth empirics. CID Working Paper Series 1999.23, Harvard University, Cambridge, MA, July 1999

Seers, D. (1970). The meaning of development. Revista Brasileira de Economía, 24(3), 29-50.

Sidik, M. (2002). Central and regional financial balance as the implementation of fiscal decentralization. In A Year Seminar on the Implementation of Regional Autonomy Policy in Indonesia, Yogyakarta.

Streeten, P., Burki, S. J., Haq, U., Hicks, N., \& Stewart, F. (1981). First things first: meeting basic human needs in the developing countries.

Suharto, E. (2005). Building communities, empowering people: Strategic studies of social welfare development and social work. Refika Aditama.

Tadjoeddin, M. Z., Suharyo, W. I., \& Mishra, S. (2001). Regional disparity and vertical conflict in Indonesia. Journal of the Asia Pacific Economy, 6(3), 283-304.

World Bank. (2003). World Development Report 1999/2000. Washington, DC: World Bank.

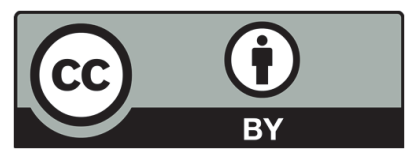

(C) 2020 by the authors; licensee Growing Science, Canada. This is an open access article distributed under the terms and conditions of the Creative Commons Attribution (CC-BY) license (http://creativecommons.org/licenses/by/4.0/). 